\title{
Comrades Marathon for short-term experiential learning as perceived by physiotherapy students: A short report
}

\begin{abstract}
This study described the learning experiences of physiotherapy students during the 2009 Comrades marathon. A qualitative approach using focus group discussions was employed for this study.

The population for this study was all the 43 B.Sc. physiotherapy final year students of the University of Limpopo, who provided physiotherapy services at the 2009 Comrades Marathon. Forty (93\%) students participated in this study. All the participants were black with majority 23 (58\%) of them from the Limpopo Province. Twenty one (52\%) of the participants were females with ages ranging between 21 and 30

Useh U, PhD'
Human A, M.PhysT²

School of Environmental and Health Sciences, North West University, Mafikeng Campus.

2 Physiotherapy Department, University of Limpopo, Medunsa Campus.

years. The field trip provided both sport specific and general learning experiences. Participants had the opportunity to handle sports injuries and athletes, work and learn as a team and were quite independent. This trip also provided participants the opportunity experiencing workplace communication and interaction, the reality of the real workplace experience of heavy workload, experience of prejudice, time management and an unsafe environment.

Despite organizational challenges of the trip, the event provided an opportunity for the participants to practice sport physiotherapy. Participants appreciated the opportunity to experience the dynamics of team and collaborative learning. To ensure effective use of this event for experiential learning, it is recommended that proper guidance and support be provided by the faculty.
\end{abstract}

KEY WORDS: COMRADES MARATHON; EXPERIENTIAL LEARNING; FIELD TRIP; SPORT PHYSIOTHERAPY.

\section{INTRODUCTION}

Since its beginning, the Comrades Marathon has continued annually with the exception of the war years from 1941 to 1945 (Comrades, 2010). The number of participants has grown tremendously over the years. During an event of this magnitude, participants seek medical attention for different sport related injuries ranging from musculoskeletal injuries to respiratory pathologies. Sanchez et al. (2006) confirms that between $2 \%$ to $8 \%$ of runners are treated for a wide range of medical problems and musculoskeletal problems account for $17 \%$. The Comrades Marathon as a tool for field learning will therefore provide physiotherapy students the opportunity to observe, assess and manage these arrays of sport injuries and conditions. Revital (2001), reiterates that field trips are complex, interactive and social learning environments, which enables binding of the curriculum to the environment and combining cognitive and affective aspects of learning.

Final year Bachelor of Science physiotherapy students from most universities in South Africa offer services to athletes as a collective at events such as the Comrades Marathon. Services provided include prophylactic massage, strapping following sport injuries and physiotherapeutic management of injuries. During this event, students are expected to use the opportunity provided by the Comrades Marathon for collaborative and experiential learning. Experience gained through life, education and work plays a central role in the process of learning (Fry et al, 2006). Students are usually involved fully and freely in new experiences, also known as "concrete experience". Beaty (2006: 135) and Cummins et al 2010, affirms that there is a difference between learning in the natural world and learning in the constructed world, in higher education. Placement, work-based learning and field trips are the methods of promoting experiential learning. The use of experiential learning has been documented in different professions; sociology (Sobal et al, 1981), medicine (Van Der Hem-Stokroos et al, 2003) and physiotherapy (Richardson, 1999). In this study a field trip such as providing sport physiotherapy services during the Comrades Marathon is meant to combine work in the classroom and work in the naturalistic setting. The advantage of a field trip is that the usual and physical impact of the surroundings brings theory to life (Beaty 2006: 140) and allows the secondary learning objectives to be met.

Corresponding author:

Prof U Useh

School of Environmental and

Health Sciences

North West University,

Mafikeng Campus

Email: 22839968@nwu.ac.za 
Despite the fact that physiotherapy students from the University of Limpopo, like other students had participated in the Comrades Marathon for the purpose of teaching and learning over the years, there is no documented evidence that the Comrades Marathon as a tool for experiential learning has achieved the specified learning goals. We therefore sought answers to the following question: 1) what were the general learning experiences of physiotherapy students during the field trip?

Kolb's experiential learning theory affirms the importance of experiential activities, such as field trips. Experiential learning is based on the notion that understanding is not a fixed or unchangeable element of thought but is formed and re-formed through experience. It is also a continuous process often repeated as cyclical and often based on experience (Fry et al, 2006). Active participation and involvement of students in real life situations are stressed. According to Sobal et al. (1981), action learning occurs as they learn by doing. Gentry (1990), reiterated that various terms are used to label the process of learning from experience: "learning by doing" "experienced-based learning"; "trial and error". Learning is used to explain the inductive learning processes; "applied experiential learning" combined experiential learning from the "real world" situation with application of concepts, ideas and theories to the interactive setting.

\section{METHODOLOGY}

The population for this study was all B.Sc. physiotherapy final year students of the University of Limpopo, Medunsa Campus, South Africa who provided physiotherapy services at the 2009 Comrades Marathon $(\mathrm{N}=43)$. During this period there are no structured teaching activities by any faculty member but students were expected to learn by applying their theoretical knowledge, i.e. by "doing". Data regarding the experiences of the students was collected using two focus group discussions and a survey questionnaire. Participants for the two focus groups were purposively chosen from the larger class of 43 and the survey participants were all students. Each focus group consisted of 6-12 members.
Before the collection of data, the two authors (UU and AH) who served as moderators assured participants that full confidentiality and anonymity was guaranteed and that respondents could withdraw from the study at any time without prejudice of any form. Informed written consent was obtained from participants. The starting question used in the focus group was: "What were your learning experiences during the Comrades Marathon?" As well as "What were the general experiences of students during this field trip?" The focus group discussions were recorded and later transcribed verbatim. The initial themes from the focus group were critically evaluated by both authors. The agreed themes were presented to two independent colleagues who are experts in qualitative research and had not attended the focus groups for verification. They agreed with the themes that were identified with a summary that was written for each theme. The report was then given to two of the participants for credibility. The results were presented to members of the group to confirm if the descriptions were a true reflection of their experience.

\section{RESULTS}

A total of 40 (93\%) students participated in this study. Three were absent on the date that data was collected. All the participants were black with the majority 23 (58\%) of them from Limpopo Province, 7 from Gauteng, 2 from KwazuluNatal, one was from Eastern Cape and North West and two were international students. Out of the participants 19 (48\%) were males and 21 (52\%) females with ages ranging between 21 and 30 years. The results of the learning experiences of the two focus group discussions are presented in Table 1.

The participants presented two different experiences: one was specific to sport physiotherapy and the other was related to the 'real working world' (general experience of the trip).

\section{DISCUSSIONS}

Participants in this study experienced learning by doing as reported by Sobal et al. (1981) and Beaty (2006) by treating sport injuries at the Comrades Marathon. Comrades Marathon as a field trip assisted in improving the practical skills of sport physiotherapy students. This was in agreement with Orion (1993) and Lave and Wenger (1991) who was of the opinion that new knowledge can be generated from practice and "hands on" activities which facilitates the construction of abstract concepts and enhancing meaningful learning. Participants also reported improving their confidence in clinical practice. According to Hudson (2008), experiential learning can be used to boost confidence. The improved confidence might be as a result of the participants making better clinical decisions and improved problem solving in the management of sport injuries. Although the learning was fun, it was hoped that active and deep learning had occurred (Hess, 1999; Wright, 2000). Participants mentioned experiencing collaborative and team learning during the field trip, interaction of students with colleagues and athletes from different socio-cultural backgrounds from other institutions and simulating real work situation, occurred during the field trip. This agrees with Wright (2000), who reports that experiential learning facilitates the transition from class to the workplace. Working with different sociocultural and diverse groups could be akin to the true South African and workplace demography. As a physiotherapist you are bound to work with persons from different backgrounds and this trip gives students the opportunity to do exactly this.

The opportunity to experience what they had learnt in class was also expressed. Collaboration and team learning was one of the experiences reported by participants. These findings agrees with those of Fisher and SavinBaden (2002), who reported that fieldwork education encourages team work, independent and ownership of the learning experience. A few students however still wanted support from faculty. The reason for this might be attributed to the different learning styles and learning spaces as reported by Orion (1993), and Kolb and Kolb (2005). A processoriented rather than content-oriented approach seemed a preferable learning strategy in field trips.

Poor preparation and other logistics related to the real world were also reported. According to Orion (1993), the importance of preparation for field 
Table 1: Summary of themes generated from the focus group discussions

\begin{tabular}{|c|c|c|}
\hline & Themes & Verbatim Quote \\
\hline \multirow[t]{2}{*}{$\begin{array}{l}\text { Learning } \\
\text { experience from } \\
\text { the field trip with } \\
\text { regard to sport } \\
\text { Physiotherapy. }\end{array}$} & $\begin{array}{l}\text { Learning opportunity } \\
\text { (Learning by doing) } \\
\text { Handling of sports injuries } \\
\text { and athletes } \\
\text { Improved confidence } \\
\text { (Learning by doing) }\end{array}$ & $\begin{array}{l}\text { 'We were given the opportunity to see what we learnt in class'. } \\
\text { 'We learnt to massage athletes before and after the race from } \\
\text { qualified physios' 'we saw the effect of therapeutic massage'. } \\
\text { Group } 1 \\
\text { 'Learning how to handle athletes'. Groups } 1 \text { and } 2\end{array}$ \\
\hline & $\begin{array}{l}\text { Collaborative and Team } \\
\text { learning and team work } \\
\text { 'Real Workplace' } \\
\text { Communications and } \\
\text { interaction within and } \\
\text { across teams }\end{array}$ & $\begin{array}{l}\text { 'We learnt how to interact with different people and colleagues from } \\
\text { different institutions, different cultural groups in real work situations' } \\
\text { and 'networking'. } \\
\text { We also learnt 'communicating with other professionals' } \\
\text { Groups } 1 \text { and } 2\end{array}$ \\
\hline \multirow[t]{2}{*}{$\begin{array}{l}\text { General } \\
\text { experience of } \\
\text { the field trip }\end{array}$} & $\begin{array}{l}\text { Real working world } \\
\text { (Sub-Themes) } \\
\text { 1. Exciting }\end{array}$ & $\begin{array}{l}\text { 'It was fun' 'Exciting', 'interesting', 'Fantabulous' 'Fantastic' and } \\
\text { 'wonderful'. 'Spending time with class members out of school' } \\
\text { 'being in the Comrades environment' 'going to Durban' and } \\
\text { 'travelling was exciting. Groups } 1 \text { and } 2\end{array}$ \\
\hline & $\begin{array}{l}\text { 2. Despondent } \\
\text { 3. Prejudice } \\
\text { 4. Unsafe environment } \\
\text { 5. Task and Workload } \\
\text { management } \\
\text { 6. Time Management } \\
\text { 7. Organisation } \\
\text { 8. Hierarchical } \\
\text { 9. Preparation for trip }\end{array}$ & $\begin{array}{l}\text { 'I did not know why we did not win anything, we were most } \\
\text { vocal during the singing competition, ... They were playing only } \\
\text { white music'. } \\
\text { We had these physios... their approach towards us was rude' } \\
\text { Both groups } \\
\text { 'There was poor lodging and travel arrangements'; 'poor time } \\
\text { management' as they were 'late for everything'; 'poor performance } \\
\text { at the inter university strapping competition'; } \\
\text { 'The trip was 'hectic', 'just a lot of work' 'poor working } \\
\text { arrangements'; limited time for socialization'; poor safety } \\
\text { and security arrangements and 'exhausting'. Both groups }\end{array}$ \\
\hline
\end{tabular}

trips and the ability of students to carry out assignments during field trips are related to the novelty of the field trip setting. It was reported that if the setting was novel, students would explore it. This "novelty space" according to Orion includes cognitive, psychological and geographical components. The idea of novelty space emphasizes the importance of adequate preparation for a trip which will therefore reduce the novelty space to a minimum and thus facilitate meaningful learning during the field trip.

\section{CONCLUSION}

It was clear that the Comrades Marathon as a field trip provided an opportunity for the students to link theory and practice of sport physiotherapy. However, adequate preparations and faculty support was observed to be necessary for a more productive field trip and short-term experiential learning. Since this was supposed to be used as learning tool, it is recommended that faculty should provide students with clear learning outcomes and assessment guidelines prior to leaving for the trip. Assessment of outcomes might be through presentations of sport specific learning experiences.
It is also recommended that students should be more involved at the preparatory stages of the trip.

\section{LIMITATIONS OF THE STUDY}

The fact that the data for this study was collected from only one of the eight participating universities limits generalization of the outcome of this study to all other students from other universities. In addition, the approach of the study and the socio-cultural composition of the population could have influenced the responses. Further study with a larger and a more diverse population is therefore recommended. 


\section{REFERENCES}

Beaty 12006 Supporting learning from experience. In H. Fry, S. Ketteridge, \& S. Marshall, A handbook for Teaching and learning in higher education: enhancing academic practice (2nd edn., pp134-147. RoutledgeFalmer, London

Comrades. 2010 Retrieved June 17th, 2010, from http://www.southafrica.info/about/sport/comrades. htm http://www.southafrica.info/about/sport/comrades.htm

Cummins A, McCloskey S, O'Shea M, O'Sullivan B, Whooley K, Savage E 2010 Field placements: an integrated and community approach to learning in children's nursing. Nurse Education in Practice (10): 108-112.

Fisher A, Savin-Baden M 2002 Modernising Fieldwork, Part 2. British Journal of Occupational Therapy, 275-282.

Fry H, KetteridgeS, Marshall, S 2006 A handbook for Teaching and Learning in Higher Education: enhancing academic practice. RoutledgeFalmer, London
Gentry J W 1990 What is experiential learning? In: Gentry JW(ed) Guide to Business Gaming and Experiential Learning. ABSEL, New York

Hess G F 1999 Principles 3: Good practice encourages active learning. Retrieved May 5, 2010, from Google Scholar: http://heinonline. org/HOL/ViewImageLocal?handle=hein.journals/ jled49\&div $=39$

Hudson Z 2008 Confidence in clinical reasoning. Physical Therapy in Sport, 9 (4),165-166.

Kolb A K, Kolb D A 2005 Learning styles and learning spaces: enhancing experiential learning in higher education. Academy of Management Learning , 4 (2), 193-212.

Lave J, Wenger E 1991 Situated Learning Legitamate peripheral participation. Cambridge University Press, Cambridge.

Orion N 1993 A model for the development and implementation of field trips as integral part of the science curriculum. School Science and Mathematics , 93 (6), 325-331.
Revital T T 2001 Incorporating field trips as science learnng environment enrichment- an interpretive study. Learning Environment Research, 4, 25-49.

Richardson B 1999 Professional Development 2: Professional Knowledge and situated learning in the workplace. Physiotherapy, 85 (9),467-474.

Sanchez L D, Corwell B, Berkoff D 2006 Medical problemms of marathon runners. The American Journal of Emergency Medicine , 24, 608-615.

Sobal J, Hinrichs DW, Emmons C F, Hook W F 1981 Experiential learning in introductory Sociology: a course description and evaluation. Teaching Sociology , 8(4), 401-422.

Van Der Hem-Stokroos H, Daelmans H, Van Der Vleuten C, Haarman H, Scherpbier A 2003 A qualitative study of constructive clinical learning experience. Medical Teacher, 25(2),120-126.

Wright M C 2000 Getting more out of less: the benefits of short-term experiential learning in undergraduate sociology course. Teaching Sociology , 28(2),116-126

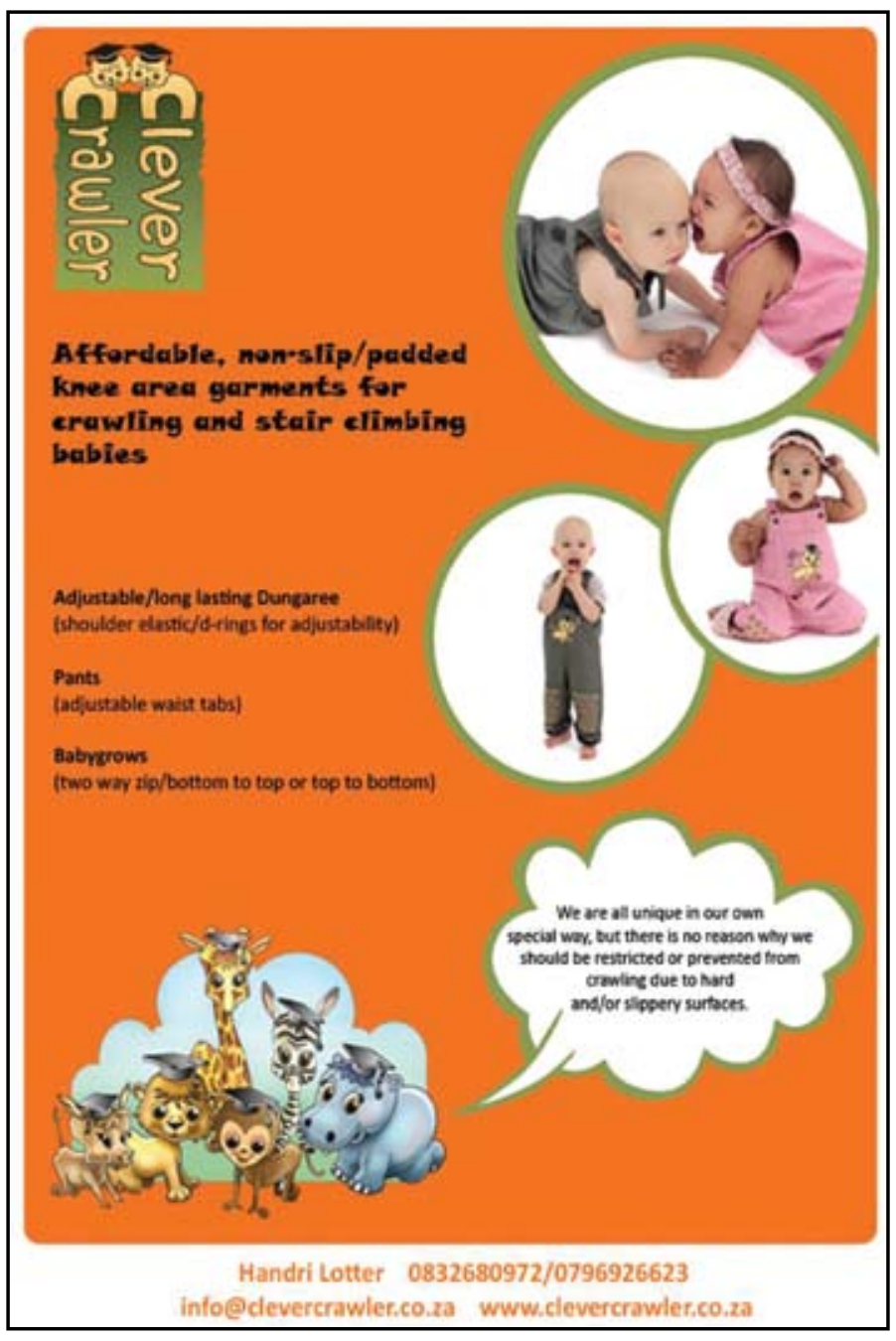

\section{Affordable, non'slip/padded knee area garments for crawling and stair climbing babie:}

(two way zip/bottom to top or top to bottom)

Gdevercrawler.co.za www.clevercrawler.co.z:

\section{What is PEDro?}

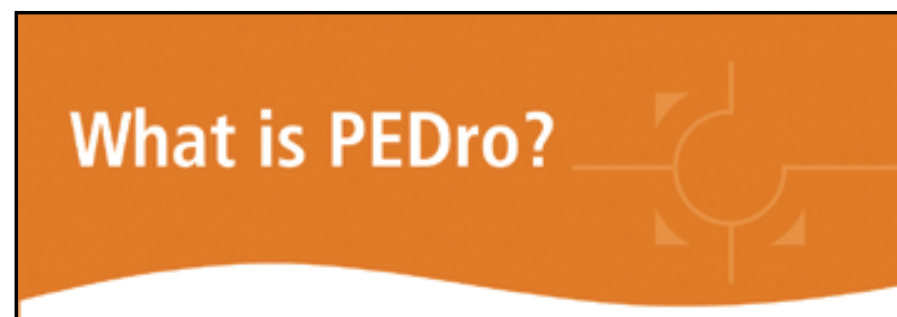

PEDro, the Physiotherapy Evidence Database, is a free, webbased database of evidence relevant to physiotherapy. PEDro provides rapid access to bibliographic details and abstracts of over 17,000 randomised controlled trials, systematic reviews and evidence-based clinical practice guidelines relevant to physiotherapy. Where possible, abstracts and links to full-text versions of the documents are also provided.

The randomised controlled trials on PEDro are rated for quality to help you discriminate quickly between trials which are likely to be valid and interpretable and those which are not. These ratings help you to judge the quality and usefulness of trials to inform clinical decision making.

\section{PEDro is free}

wwww.pedro.org.au

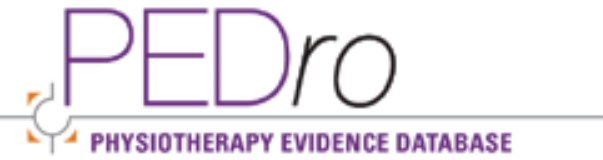

